\title{
A new ornithomimid dinosaur from the Upper Cretaceous Packard Shale Formation (Cabullona Group) Sonora, México
}

Claudia Inés Serrano-Brañas ${ }^{1}$, Esperanza Torres-Rodríguez ${ }^{2}$, Paola Carolina Reyes-Luna ${ }^{3}$, Ixchel González-Ramírez ${ }^{4}$, Carlos González-León ${ }^{5}$

${ }^{1}$ Facultad de Ciencias, Universidad Nacional Autónoma de México, Circuito Exterior,

Ciudad Universitaria, Coyoacán, 04510 México, D.F., México.

${ }^{2}$ Posgrado en Ciencias de la Tierra, Instituto de Geología, Universidad Nacional

Autónoma de México, Circuito Exterior, Ciudad Universitaria, Coyoacán, 04510 México, D.F., México.

${ }^{3}$ Earth and Planetary Sciences, McGill University, 3450 University Street, Montreal, Quebec, Canada, H3A OE8

${ }^{4}$ Posgrado en Ciencias Biológicas, Instituto de Geología, Universidad Nacional

Autónoma de México, Circuito Exterior, Ciudad Universitaria, Coyoacán, 04510 México, D.F., México.

${ }^{5}$ Estación Regional del Noroeste, Instituto de Geología, Universidad Nacional Autónoma de México, Apartado Postal 1039, 83000 Hermosillo, Sonora, México.

Corresponding author: Claudia Inés Serrano Brañas. E-mail:

claudiabran399@gmail.com

Postal Address: Viaducto Miguel Alemán \#5 Esquina División del Norte; Colonia del Valle; Delegación Benito Juárez; C.P. 03100, México, D.F. 


\begin{abstract}
New ornithomimid material discovered from the Upper Cretaceous Packard Shale Formation, (Cabullona Group) of Sonora, Mexico is described. The material includes a partial skeleton, which is assigned to a new genus and species, Tototlmimus packardensis. This new taxon differs from other ornithomimids in having five unique characteristics that separate it from other northamerican ornithomimids: (1) a distinctively articulation between metatarsals, where the distal ends of metatarsals II and IV contact directly with the distal facet of metatarsal III; (2) a metatarsal III with a weakly ginglymoid distal articular face; (3) the medial and lateral sides of metatarsal III are shaped into the form of metatarsals II and IV, so all distal ends fit together when they articulate; (4) an asymmetrical and narrow pedal ungual with shallow grooves in both medial and lateral sides; and finally, (5) the presence of a deep sulcus on the ventromedial edge, close to the articular end. Phylogenetic analysis suggests that Tototlmimus packardensis corresponds to a derived ornithomimid included in the Northamerican clade, forming a monophyly with Ornithomimus. Tototlmimus packardensis is the first definitive ornithomimid described for Mexico, and represents one of the southernmost occurrences in the Western Interior Basin of North America.
\end{abstract}

Keywords: Dinosaurs, Theropods, Ornithomimosauria, Ornithomimidae, Tototlmimus packardensis, Packard Shale Formation, Late Cretaceous, Sonora, Mexico.

\title{
1. Introduction
}

Ornithomimosaurian dinosaurs were a group of lightly built, medium to large size, cursorial theropods with rather long forelimbs. These organisms lived in the Northern 
Hemisphere during Cretaceous times and are common elements of many Northamerican and Asian dinosaur faunas (Barsbold and Osmólska, 1990). The earliest and most basal taxa, Pelecanimimus and Shenzhousaurus were relatively small in size, in comparison with Gallimimus bullatus who could reach a body length of eight meters (Ji et al., 2003; Macovicky et al., 2010).

Most ornithomimid genera are known from Asia and only Ornithomimus and Struthiomimus, are currently known from the Upper Cretaceous of North America (Marsh, 1890; Osborn, 1917; Makovicky et al., 2004; Longrich, 2008). Ornithomimus is characterized by gracile forelimbs, elongate first metacarpals (Russell, 1972) and a straight ventral edge of the maxilla (Parks, 1928). The genus includes two species: Ornithomimus edmontonicus (Sternberg, 1933) and Ornithomimus velox (Marsh, 1890). On the other hand, Struthiomimus has robust limbs, short first metacarpals (Russell, 1972) and a strongly convex maxillary ventral edge (Osborn, 1917). Struthiomimus altus (Osborn, 1917) is the only valid species included in this genus at present.

Several ornithomimid fossils have been collected along the interior margin of Western North America, which cannot be assigned to either one of these genera because of their distinctive morphology (Longrich, 2008; Aguillón-Martínez, 2010). Particularly in Mexico, ornithomimid material is common among continental vertebrate faunas, but it consists of isolated bones (Torres-Rodríguez, 2006). In this work we described and analyzed a new genus and species of ornithomimosaur from the Packard Shale Formation, Cabullona Group (Upper Cretaceous) in northeastern Sonora, Mexico. This formation is characterized by a rich assemblage of fresh-water invertebrates, plants and dinosaurs.

\section{Geological setting}


The Cabullona basin is a continental depocenter at least $80 \mathrm{~km}$ long and $30 \mathrm{~km}$ wide that formed in northeastern Sonora during Late Cretaceous (Figure 1a). Its fluvial to lacustrine sedimentary fill is near $4 \mathrm{~km}$ thick and has an age between 80 and $70 \mathrm{Ma}$ (González-León et al., 2014). It extends into southeastern Arizona where it correlates with the Fort Crittenden Formation. The 2.5-km thick Cabullona Group that was first described by Taliaferro (1933) crops out $\sim 20 \mathrm{~km}$ south of the town of Naco and forms the youngest part of the Cabullona basin's fill.

The outcrops south of Naco form the type section of the Cabullona Group which includes, from base upwards the Corral de Enmedio, Camas Sandstone, Packard Shale and Lomas Coloradas formations (Figure 1b). These units represent fluvial and lacustrine facies while the lateral equivalent, El Cemento Conglomerate represents alluvial fan facies (González-León and Lawton, 1995). The age for the type section of the Cabullona Group is constrained to $72 \mathrm{Ma}$, according to two $\mathrm{U}-\mathrm{Pb}$ ages obtained from volcanic tuffs. One of the samples was collected from the lower part of the Corral de Enmedio formation and the other is from the upper part of Lomas Coloradas Formation (López-Higuera et al., 2008, González-León et al., 2014).

Remains of vertebrates, such as dinosaurs, crocodiles, turtles and fishes, are common in all the formations as reported by Lucas et al. (1995) and Serrano-Brañas et al. (2014). The bones herein reported were collected from shallow lacustrine, massive, dark gray shales, which correspond to the lower part of Member 2 of the Packard Shale Formation (Figure 1b). 
The specimen described and discussed in this paper is housed at the paleontological collection of the Estación Regional del Noroeste (ERNO) in Sonora, Mexico.

Institutional abbreviations: AMNH, American Museum of Natural History, New York, USA; CMN, Canadian Museum of Nature, Canada; ERNO, Estación Regional del Noroeste, Hermosillo, Sonora, Mexico; GIN, Paleontological Center of Mongolian Academy of Science, Ulaanbaatar, Mongolia; IVPP, Institute of Vertebrate Paleontology and Paleoanthropology, Beijing, China; MPD, Mongolian Paleontology Dinosaur, Paleontological Center of Mongolia, Ulaan Bataar, Mongolia; ROM, Royal Ontario Museum, Toronto, Ontario, Canada; TMP, Royal Tyrrell Museum of Palaeontology, Drumheller, Alberta, Canada; UCMZ, Museum of Zoology, University of Calgary, Calgary, Alberta, Canada; USNM, Smithsonian Institution National Museum of Natural History, Washington DC, USA; YM, Peabody Museum of Yale University; ZPAL, Institute of Paleobiology, Polish Academy of Sciences, Warsaw, Poland.

\section{Systematic Paleontology}

Order Dinosauria Owen, 1842

Saurischia Seeley, 1888

Theropoda Marsh, 1881

Ornithomimosauria Barsbold, 1976

Family Ornithomimidae Marsh, 1890

Genus Tototlmimus gen. nov.

Type species: $T$. packardensis sp. nov., by monotypy. 
Etymology: The generic name is based on Tototl which is the Náhuatl word for bird; Greek mimus refers to mimic.

Diagnosis: As for the type and only species.

Species T. packardensis sp. nov.

Etymology: Referring to its occurrence in the Packard Shale Formation.

Holotype: ERNO 8553. Fragments of manus and pes that includes left manual phalanx I-1 and right manual phalanges III-1, III-2; right metatarsals II, III and IV; right pedal phalanges II-1, II-2, III-2, III-3, IV-1, IV-3, IV-4; left phalanges II-1 and II-2, and left pedal ungual.

Type locality. A locality $1 \mathrm{~km}$ east-southeast of rancho Corral de Enmedio.

Stratigraphic horizon. Packard Shale Formation, Cabullona Group; Upper Cretaceous (Campanian).

Measurements. Table 1.

Diagnosis: An ornithomimid dinosaur that possesses the following characteristics: a very distinctively articulation between metatarsals, where the distal ends of metatarsals II and IV contact directly with the distal facet of metatarsal III; a metatarsal III with a weakly ginglymoid distal articular facet that bears some pits and deep longitudinal scars; also, the medial and lateral sides of this element are shaped in the form of metatarsals II and IV, so all distal ends fit together when they articulate; an asymmetrical and narrow pedal ungual with shallow grooves in both medial and lateral sides; it also possesses a ventromedial edge with a deep sulcus close to the articular end and ventrolateral edge with a prominent keel; finally, the ventral surface of this element do not has a flexor tubercle, instead it is weakly concave and contains small foramina. 


\subsection{Description.}

The bones of Tototlmimus packardensis were surfacing within a small glen of about $50 \mathrm{~cm}$ deep and collected in an area of 50x50 $\mathrm{cm}^{2}$. Most of the fossils were disarticulated with the exception of some phalanges and did not have a preferential orientation. Bone configuration suggests that all fossils belong to one individual. Measurements of the preserved elements are shown in table 1.

Manual phalanges.- The distal articular end of left phalanx I-1 is preserved (Figures 2a). In distal view, this articular facet is ginglymoid in order to articulate with manual ungual I (Figure 2a3). The distal condyle is rounded and has a deeply ovoid collateral fossa; while the lateral condyle is broken and bears a shallower lateral fossa (Figures 2a2). Only the proximal ends of right phalanges III-1 and III-2 are preserved (Figures $2 \mathrm{~b}-2 \mathrm{c}$ ). These portions are transversely wide and their articular surface has an ovoidal shape (Figures 2b1$2 \mathrm{~b} 3$ and $2 \mathrm{c} 1-2 \mathrm{c} 3$ ). The flexor surface in both phalanges is flat (Figures $2 \mathrm{~b} 2$ and $2 \mathrm{c} 2$ ). The proximal articular facet of phalanx III- 1 is slightly concave, whereas in phalanx III-2 this facet bears a ridge in order to articulate with the distal intercondylar groove of phalanx III-1 (Figures $2 \mathrm{~b} 3$ and 2c3).

Metatarsals.- The distal portions of the right metatarsals II, III and IV are preserved (Figure 3). These elements are broken at the diaphysis approximately $30 \mathrm{~mm}$ from the distal end. In cross-section, the diaphysis of metatarsals II and IV is subcircular, whereas in metatarsal III is more subrectangular. Although the shafts are broken, the articulation of metatarsal II and IV with metatarsal III suggest that their contact surfaces curved, corresponding to the shape of metatarsal III. Therefore, the proximal articular surface of metatarsal III would be 
excluded from the ankle joint, because of the contact between metatarsals II and IV (Figure 3d1). Both sides of metatarsal III (medial and lateral) are shaped in the form of metatarsals II and IV, so all distal ends fit together when they articulate (figure $3 \mathrm{~d} 1$ and $3 \mathrm{~d} 2$ ). The distal articular facet of metatarsals II and IV is smooth and rounded in outline (Figures 3a1 and 3c1), while in metatarsal III this facet is weakly ginglymoid and bears some pits and deep longitudinal scars that run into an extensor-flexor direction (Figure $3 b 1$ and 3b4). Medial distal condyles of metatarsals IV and III are larger and wider than the lateral ones; in metatarsal II these condyles are separated by a deep sulcus on the flexor side (Figure 3a4), but in metatarsal III they are separated by a shallow sagittal depression (Figure 3b4). Distal condyle of metatarsal II bears a deep and large collateral fossa on medial side, whereas the collateral fossa on the lateral side is almost imperceptible (Figures $3 \mathrm{a} 2$ and $3 \mathrm{a} 3$ ). On the contrary, the distal condyle in metatarsal III has a shallower ovoid collateral fossa on medial side and the lateral condyle possess a deep ovoidal collateral fossa (Figures 3b2 and $3 b 3)$.

The distal articular facet of metatarsal IV is expanded in the extensor and flexor directions, forming a condylar surface that is anteroposteriorly longer than mediolaterally broad. The lateral condyle is narrow in a mediolateral direction and extends further posteriorly than the medial condyle. Both condyles are separated by a deep intercondylar sulcus on flexor side (Figure 3c4). In medial view, the collateral fossa of the epiphyseal region is ovoid and deep, whereas the lateral collateral fossa on lateral side is very shallow (Figures $3 \mathrm{c} 2$ and $3 \mathrm{c} 3$ ).

Pedal phalanges.- The proximal end of left phalanx III-1 is preserved (Figures 4a). The flexor surface is flat (Figure 4a2). whereas the proximal surface is concave and has an oval 
outline (Figures 4a3). The proximal ends of the right and phalanx II-1 are preserved (Figure 4b). These portions are transversely wide and their articular surfaces have a subrectangular concave shape. In dorsal view, these surfaces bear some pits and a large deep scar that runs transversely (Figure 4b4). The flexor surface portion is flat (Figure 4b2). Right and left phalanges II-2 are also preserved (Figure 5a). The proximal articular surface bears a ridge for the articulation with the intercondylar groove of phalanx II-1 (Figure 5a4). In proximal view, this intercondylar ridge and the dorsal process are slightly positioned laterally. The flexor surface of the proximal portion is flat (Figure 5a2). In distal view, the distal condyle has the same size as the lateral one and both of them are separated by a shallow intercondylar sulcus (Figure 5a5). The collateral fossa has an overall ovoid shape and is deeper than the lateral fossa.

Right Phalanx III-2 is represented by its proximal end, which has a slightly concave surface and a notch on the dorsal edge (Figure 4c1). The flexor surface is flat (Figure 4c2). On the other hand, right phalanx III-3 is small, block-like and it is broken at its proximal and distal ends (Figure 5b).

The proximal end of right phalanx IV-1 is preserved (Figure 4d). Its articular surface is slightly concave and is expanded in an extensor - flexor direction, making it anteroposteriorly longer than mediolaterally broad (Figure $4 \mathrm{~d} 1$ and $4 \mathrm{~d} 2$ ). The flexor surface portion bears a deep ridge that runs in a longitudinal direction (Figure 4d3). Right phalanges IV-3 and IV-4 are small, block-like and highly ginglymoid (Figure 5c). Like the other phalanges, the distal condyles have deep collateral fossae.

The proximal end of a left pedal ungual is preserved (Figure 5d). This bone is asymmetrical with its main axis curved laterally and a proximodorsal process poorly develop (5d1 and 5d2). It relatively narrow in ventral view and the ventral edges are 
relatively straight. Both medial and lateral sides bear shallow grooves, but the one in the medial surface is more evident (Figure 5d2). The ventromedial edge possess a deep sulcus close to the articular end (5d2), whereas the ventrolateral edge has a prominent keel $(5 \mathrm{~d} 3)$. The articular surface is shallow, weakly ginglymous and triangular in cross-section (5d4); the ventral surface is weakly concave and contains two small foramina. The flexor tubercle is absent.

\section{Discussion}

\subsection{Ornithomimid features of Tototlmimus packardensis}

This specimen was referred to the Ornithomimidae family on the basis of the presence of an arctometatarsalian pes (Holtz, 1995), and a pedal ungual that has a triangular articular surface in cross-section, relatively straight ventral edges, a ventrolateral edge developed into a keel (closer to the articular end), and a flat ventral depression instead of a flexor tubercle (Barsbold and Osmólska, 1990).

\subsection{Morphological comparisons to other ornithomimosaurs}

In general, it has been assumed that postcranial elements are not diagnostic; however, this is not necessary the case as has been stated before (Longrich, 2008). Depending on the taxa, particular postcranial bones can be identified to family, genus or species level, and even in some cases, they allow recognition of a new species (Kobayashi, 2004; Longrich, 2008).

Comparisons with northamerican genera Ornithomimus and Struthiomimus suggest that Tototlmimus packardensis does not correspond to a known specimen of either genus, 
so it represents a distinct ornithomimid taxon. Also, it is different from any of the known Upper Cretaceous Asian Ornithomimids.

Tototlmimus packardensis metatarsals have several differences in comparison to other ornithomimids previously described. Both sides of the distal shaft of metatarsal III (medial and lateral) in T. packardensis are shaped into the form of metatarsals II and IV, so the medial surface of metatarsal II shows a direct contact with the one of metatarsal III, and extends far distally unto its distal articular facet, where it becomes deeper and articulates perfectly with the one of metatarsal III (Figure $3 \mathrm{~d} 1$ and $3 \mathrm{~d} 2$ ). This distal facet possesses two small and deep transversal scars near its medial edge (Figure 3d2). The medial surface of metatarsal IV, also exhibits a direct contact with metatarsal III, but this contact extends a little less distally than that in metatarsal II (Figure $3 \mathrm{~d} 1$ and 3d2). Regarding other ornithomimids, the contact between metatarsals is different because their distal facets articulate on a higher position with the shaft of metatarsal III, and not with its distal end as in T. packardensis (Figure 6; Osborn, 1916; Osmólska et al. 1972; Kobayashi and Lü, 2003; Kobayashi and Barsbold, 2005); and even in some cases, the distal end of metatarsals II and IV tends to diverge laterally from metatarsal III (Aguillón-Martínez, 2010; Xu et al. 2011). Furthermore, metatarsal III in T. packardensis has a weakly ginglymoid distal articular facet that bears some pronounce pits and deep longitudinal scars, which serve for anchoring the cartilage, whereas in other ornithomimosaurs this facet is smoothly rounded instead of being ginglymoid or weakly ginglymoid (Figure 7; Osmólska and Barsbold, 1990).

It is well known that metatarsal and interphalangeal articulation morphology could be indicative of the countering stress incurred during foot use. Non- or weakly ginglymoid articulations are indicative of low torsional stress, and are especially prevalent in cursorial 
taxa (e.g. Ornithomimids), whereas ginglymoid articulations limit joint movement to a single plane, giving more resistance to torsion but decreasing foot flexibility (Fowler et al. 2011). Most ornithomimids have smooth and rounded metatarsal distal facets, which articulate at different levels with metatarsal III. Even some specimens possess divergent distal ends (II and IV) that could suggest the presence of broader feet and splayed toes (Aguillón-Martínez, 2010; Xu et al. 2011). It is clear that metatarsal features of Tototlmimus packardensis -particularly of digits II and III- reflect a more extensive and reinforced area for cartilage anchorage, probably in response to a rapid locomotion displacement with narrower feet and toes, where the main weight of the animal still relied on digit III, whereas digits II and IV performed a stabilization role.

Regarding the pedal ungual of Tototlmimus packardensis, it corresponds to an asymmetrical narrow claw with a proximodorsal process poorly develop. Although, the ventral edges of this bone are straight as in other ornithomimosaurs, the lateral and medial sides of this claw bear shallow grooves instead of the deep ones seen in the rest of the ornithomimids. Its ventromedial edge possess a deep sulcus close to the articular end (5d2), whereas the ventrolateral edge has a prominent keel (5d3). Finally, the ventral surface in Tototlmimus packardensis possesses a flat depression instead of a flexor tubercle (Figure $8 \mathrm{e} 4)$.

Comparing the pedal ungual of Tototlmimus packardensis with the Asian ornithomimids, we can observe that it is different from any of them. Garudimimus and Harpymimus possess pedal claws that bear strong flexor tubercles with deep excavations on either side (Kobayashi and Barsbold, 2005). Anserimimus and Qiupalong possess short, subtriangular, slightly curved and ventrally flat pedal unguals, with laterally deep grooves (Xu et al. 2011; Bronowicz, 2011). Pedal unguals in Archaeornithomimus have flat ventral 
surfaces, and their posterior part have a depression with a weak longitudinal ridge but not a flexor tubercle (Kobayashi and Lu, 2003). In Beishanlong, the claws bear shallow ventral depressions surrounding the highly reduced flexor tubercle (Makovicky et al. 2009). Nor of these genera possess shallow lateral grooves on the lateral and medial sides of the claw (with the exception of Beishanlong, however its unguals are different from those of Tototlmimus packardensis because they possess a reduced flexor tubercle) or even a sulcus in the ventromedial edge. Until now, there have not been recovered any pedal unguals for Pelecanimimus (Pérez-Moreno et al. 1995) or Shenzousaurus (Ji et al. 2003), so a direct comparison with Tototlmimus packardensis was not possible.

On the other hand, the northamerican genus Ornithomimus has elongated and weakly curved to straight pedal unguals, which are narrow in ventral view, with ventral surfaces weakly concave, laterally deep grooves, sharp ventrolateral edges and a poorly develop proximodorsal process (Figure 8a-b). In Struthiomimus altus, the pedal unguals are moderately curved, relatively broad in ventral view, with laterally deep grooves, rounded ventrolateral edges and with a proximodorsal process reduced but distinct (Figure 8c-d; Longrich, 2008). Ornithomimus and Struthiomimus have articular surfaces that tend to be shallow and weakly ginglymous, a diminutive or absent flexor tubercle, a shallow flexor depression, and a series of small sulci in this area that contain blood vessel foramina. Both of them lack a sulcus in their ventromedial edges (Figure 8). Tototlmimus packardensis pedal unguals are distinguished from those of Ornithomimus and Struthiomimus based on the presence of shallow grooves on the lateral and medial sides of the claw and a sulcus in its ventromedial edge (Figure 8e1, 8e2 and 9). Finally, Longrich (2008) reported a new large ornithomimid from the Upper Cretaceous Dinosaur Park Formation (ROM 41844), which was different from the previously known Canadian ornithomimids Struthiomimus 
and Ornithomimus (Xu et al. 2011). This specimen has strongly curved pedal unguals with an articular surface strongly angled relative to the distal end of the ungual, a proximodistal process long, broad, and tongue shaped, and a flexor tubercle develop as a prominent ridge. Tototlmimus packardensis possess a shallow and weakly ginglymous articular surface, and lacks a flexor tubercle in the pedal ungual, so it is not related to the Dinosaur Park giant species.

\subsection{Phylogenetic position of Tototlmimus packardensis}

In order to explore the relationship between $T$. packardensis and other dinosaurs we performed a phylogenetic analysis using the main coelurosaurian taxa. A matrix of 74 terminals and 292 characters were constructed (Appendices 1 and 2). All characters are equally weighted and unordered. Characters 0 to 235 were derived from Makovicky et al (2010), 236 to 250 were taken from Turner et al. (2007), and 251 to 292 were characters added by P. Makovicky in order to resolve the position of several basal coelurosaur taxa. Codings follow Makovicky et al. (2010). Dilophosaurus was chosen as outgroup. Characters and character state are described in Appendix 1. Parsimony analysis was performed using TNT software (Goloboff et al., 2003). Parsimony analysis consisted in a combined analysis of Sectorial Search, Ratchet, Drift and Tree Fusing.

This analysis produced 2105 most parsimonious trees of 1010 steps, with a C.I. = 0.34 and a R.I. $=0.70$. From these most parsimonious trees, a strict consensus tree was obtained of 1200 steps, with a C.I. $=0.29$ and a R.I. $=0.62 ;$ which showed that Tototlmimus is positioned within Ornithomimosauria (Figure 10). 
On the other hand, in order to explore more deeply the relationship between Tototlmimus packardensis and other ornithomimids we performed a more specific phylogenetic analysis. Another matrix of 13 terminals and 41 characters was constructed (Appendices 3 and 4). All characters are equally weighted and unordered. Characters 0 to 35 were derived from Kobayashi and Lü (2003), 38 to 40 were taken from Makovicky et al. (2010), and two new additional characters were included (36 and 37). Codings follow Kobayashi and Lü (2003) and Makovicky et al. (2010). Allosaurus and three Tyrannosaurids have been chosen as outgroups; 11 ornithomimosaur taxa were selected for this analysis (Table 2). Characters and character state are described in Appendix 3. Parsimony analysis was performed using TNT software (Goloboff et al., 2003) with 38 potentially informative characters. Parsimony analysis consisted in a combined analysis of Sectorial Search, Ratchet, Drift and Tree Fusing.

This analysis produced two most parsimonious trees of 62 steps, with a C.I. $=0.640$ and a R.I. $=0.730$. General topology of both trees is similar to the one proposed by Kobayashi and Lü (2003), Kobayashi and Barsbold (2004) and Xu et al. (2011). From these two most parsimonious trees, a strict consensus tree was obtained of 70 steps, with a C.I. $=$ 0.570 and a R.I. = 0.620; which showed an unresolved polytomy between Struthiomimus, Ornithomimus, Sinornithomimus and Tototlmimus (Figure 11a). Because the polytomy of this consensus tree was determined by the two possible positions of Tototlmimus packardensis, the phylogenetic discussion will focus on these tree topologies.

The first tree recovered, only shows that Tototlmimus is positioned within Ornithomimidae based on the arctometatarsalian condition (character 34; Figure 11b): Archaeornithomimus + Tototlmimus + Sinornithomimus $+($ Gallimimus + Anserimimus $)+$ Struthiomimus + Ornithomimus). However, the second tree (11c) is more informative 
because it shows that Tototlmimus corresponds to a derived ornithomimid placed in the "Northamerican clade" proposed by Kobayashi and Lü (2003): Archaeornithomimus + Sinornithomimus $+($ Gallimimus + Anserimimus $)+$ Struthiomimus $+($ Ornithomimus + Tototlmimus).

Tototlmimus seems to be more related to Ornithomimus than to Struthiomimus (Figure 11c). However, Tototlmimus represents a different taxon because it possesses five unique characteristics that separate it from other northamerican ornithomimids: (1) a distinctively articulation between metatarsals, where the distal ends of metatarsals II and IV contact directly with the distal facet of metatarsal III; (2) a metatarsal III with a weakly ginglymoid distal articular face; (3) the medial and lateral sides of metatarsal III are shaped in the form of metatarsals II and IV, so all distal ends fit together when they articulate; (4) an asymmetrical and narrow pedal ungual with shallow grooves in both medial and lateral sides; and finally, (5) the presence of a deep sulcus on the ventromedial edge, close to the articular end.

\section{Conclusions}

The specimen described here provides evidence for the recognition of a new genus and species of ornithomimid in the Late Cretaceous of southern North America. This new taxon adds to the diversity of Late Campanian ornithomimids and represents one of the southernmost occurrences in the Western Interior Basin. Although the limited diagnostic information of the holotype and only known specimen Tototlmimus packardensis, it possesses a set of particular characteristics that make it unique among the rest of the known Northamerican and Asian ornithomimids. 


\section{Acknowledgements}

The authors want to thank the Smithsonian Institution National Museum of Natural History for allowing us to use the collections of the Paleobiology Department extensively for comparison. We also want to thank MSc. Brad McFeeters (ROM) and Dr. Brandon Strilisky (TMP) for allowing the reproduction of the photographic material of ornithomimid specimens. Finally, we want to thank the reviewers for their detailed and thoughtful reviews that greatly improved the preparation of this manuscript.

\section{References}

- Aguillón-Martínez, M. C., 2010. Fossil vertebrates from the Cerro del Pueblo Formation, Coahuila, Mexico, and the distribution of Late Campanian (Cretaceous) terrestrial vertebrate faunas. Unpublished M.Sc. Thesis. Graduate Faculty of Dedman College, Southern Methodist University, p. 118.

- Bakker, R. T., Williams, M., Currie, P.J., 1988. Nanotyrannus, a new genus of pygmy tyrannosaur from the Latest Cretaceous of Montana. Hunteria 1, 1-30.

- Barsbold, R., 1976. On the evolution and systematics of the late Mesozoic dinosaurs [in Russian]. In: Kramarenko, N. N. (Ed.), Paleontologiâ i Biostratigrafiâ Mongolii. Sovmestnaâ Sovetsko-Mongolskaâ Paleontologičeskaâ Ekspediciâ, Trudy 3, 68-75.

- Barsbold, R., 1981. Toothles carnivorous dinosaurs of Mongolia [in Russian]. Sovmestnaâ Sovetsko-Mongolskaâ Paleontologičeskaâ Ekspediciâ, Trudy 15, 2839.

- Barsbold, R., 1988. A new Late Cretaceous ornithomimid from the Mongolia People’s Republic. Paleontologicheskiy Zhurnal, 122-125. 
- Barsbold, R., Perle, A., 1984. On first new find of a primitive ornithomimosaur from the Cretaceous of the MPR [in Russian]. Paleontologičeskij ẑurnal 2, 121-123.

- Barsbold, R., Osmólska, H., 1990. Ornithomimosauria. In D. Weishampel, P. Dodson and H. Osmólska (Eds.). The Dinosauria. University of California Press, Berkeley, pp. 225-244.

- Bronowicz, R., 2011. New material of a derived ornithomimosaur from the Upper Cretaceous Nemegt Formation of Mongolia. Acta Paleontologica Polonica 56 (3), $477-488$.

- Carr, T. D., 1999. Craniofacial ontogeny in Tyrannosauridae (Dinosauria, Coelurosauria). Journal of Vertebrate Paleontology 19, 497-520.

- Choiniere, J. N., Forster, C. A. and de Klerk, W. J., 2012. New information on Nqwebasaurus thwazi, a coelurosaurian theropod from the Early Cretaceous Kirkwood Formation in South Africa. Journal of African Earth Sciences 71-72: 117.

- Currie, P. J., 1995. New information on the anatomy and relationships of Dromeosaurus albertensis (Dinosauria: Theropoda). Journal of Vertebrate Paleontology 15, 576-591.

- DeCourten, F.L., Russell, D. A., 1985. A specimen of Ornithomimux velox (Theropoda Ornithomimidae) from the terminal Cretaceous Kaiparowitz Formation of southern Utah. Journal of Paleontology 59, 1091-1099.

- Fowler, D.W., Freedman, E.A., Scanella, J.B., Kambic, R.E., 2011. The predatory ecology of Deinonychus and the origin of flapping in birds. PLoS ONE 6(12): e28964, doi: 10.1371/journal.pone.0028964 
- Gilmore, C. W., 1933. On the dinosaurian fauna of the Iren Dabasu Formation. Bulletin of the American Museum of Natural History 67, 23-78.

- Goloboff, P., J. Farris, and K. Nixon. 2003. T.N.T.: Tree Analysis Using New Technology. Program and documentation, available from the authors, and at www.zmuc.dk/public/phylogeny.

- González-León, C. M., Lawton, T. F., 1995. Stratigraphy, depositional environments, and origin of the Cabullona basin, northeastern Sonora. In: JacquesAyala, C., González-León, C. M., and Roldán-Quintana, J., (Eds.), Studies on the Mesozoic of Sonora and Adjacent Areas: Boulder, Colorado, Geological Society of America Special Paper 301, 121-142.

- González-León, C. M., Solari, L., Madhavaraju, J., Villanueva-Amadoz, U., 2014, Evolution of the Late Cretaceous (Campanian) Cabullona Basin in Sonora: regional stratigraphy and U-Pb geochronology. Sociedad Geológica Mexicana, Convención Nacional Memorias, 22-23.

- Holtz, T. R. Jr., 1994. The phylogenetic position of the Tyrannosauridae: implications for theropod systematics. Journal of Paleontology 68, 1100-1117.

- Holtz, T. R. Jr., 1995. The arctometatarsalian pes, an unusual structure of the metatarsus of Cretaceous Theropoda (Dinosauria: Saurischia). Journal of Vertebrate Paleontology 14, 480-519.

- Hurum, J. H., 2001. Lower jaw of Gallimimus bullatus. In Tanke, D. H. and Carpenter, K. (Eds.), Mesozoic Vertebrate Life. Indiana University Press, Bloomington, pp. 34-41. 
- Ji, Q., Norell, M. A, Makovicky, P. J., Gao, K.-Q., Ji, S.-A., Yuan, C., 2003. An early ostrich dinosaur and implications for ornithomimosaur phylogeny. American Museum Novitates 3420, 1-19.

- Kobayashi, Y., 2004. Asian Ornithomimosaurs. Unpublished PhD Thesis. Southern Methodist University, p. 340.

- Kobayashi, Y., Lü, J. C., 2003. A new ornithomimid dinosaur with gregarious habits from the Late Cretaceous of China. Acta Palaeontologica Polonica 48 (2), 235-259.

- Kobayashi, Y., Barsbold, R., 2004. Phylogeny or Ornithomimosauria and its paleobiogeographic implications. In Proceedings of the $19^{\text {th }}$ International Congress of Zoology , Beijing, China, 23-27 August 2004, China Zoological Society, Beijing, China, pp. 50-52.

- Kobayashi, Y., Barsbold, R., 2005. Reexamination of a primitive ornithomimosaur, Garudimimus brevipes Barsbold, 1981 (Dinosauria: Theropoda), from the Late Cretaceous of Mongolia. Canadian Journal of Earth Sciences 42, 1501-1521.

- Lambe, L. M., 1902. New genera and species from the Belly River Series (midCretaceous). Geological Survey of Canada, Contributions to Canadian Paleontology $3,25-81$.

- Lambe, L. M., 1914. On a new genus and species of carnivorous dinosaur from the Belly River Formation of Alberta, with a description of the skull of Stephanosaurus marginatus from the same horizon. The Ottawa Naturalist 28, 13-20. 
- Lee, Y-N., Barsbold, R., Currie, P. J., Kobayashi, Y., Lee, H-J, Godefroit, P., Escuillié, F. and Chinzorig, T., 2014. Resolving the long-standing enigmas of a giant ornithomimosaur Deinocheirus mirificus. Nature 515 (7526): 257-260.

- Longrich, N., 2008. A new large ornithomimid from the cretaceous Dinosaur Park Formation of Alberta, Canada: Implications for the study of dissociated dinosaur remains. Paleontology 51 (4), 983-997.

- López-Higuera, A., Martínez-Hernández, E., González-León, C.M., 2008. Upper Cretaceous pollen from the Cabullona basin, northeastern Sonora, Mexico: 12th International Palynological Congress, $8^{\text {th }}$ international Organization of Paleobotany Conference, Abstract Volume, Bonn Germany, Terra Nostra, 424.

- Lucas, S. G., Kues, B. S., González-León, C. M., 1995. Paleontology of the Upper Cretaceous Cabullona Group, northeastern Sonora. In: Jacques-Ayala, C., González-León, C. M., and Roldán-Quintana, J., (Eds.), Studies on the Mesozoic of Sonora and Adjacent Areas: Boulder, Colorado, Geological Society of America Special Paper 301, 143-165.

- Madsen, J. H. Jr., 1976. Allosaurus fragilis: a revised osteology. Utah Geological Survey Bulletin 109, 1-163.

- Makovicky, P. J., 1995. Phylogenetic aspects of the vertebral morphology of Coelurosauria (Dinosauria: Theropoda). Unpublished M.Sc. Thesis, Copenhagen University, Denmark.

- Makovicky, P. J. and Norrell, M. A., 2004. A partial ornithomimid braincase from Ukhaa Tolgod Mongolia). American Museum Novitates 3247, 1-16. 
- Makovicky, P. J., Kobayashi, J., and Currie, P. J., 2004. Ornithomimosauria. In: Weishampel, D.B., Dodson, P. and Osmólska, H. (Eds.), The Dinosauria, $2^{\text {nd }}$ edition. University of California Press, Berkeley, pp. 137-150.

- Makovicky, P. J., Li, D., Gao, K.-Q., Lewin, M., Erickson, G. M., Norell, M. A., 2010. A giant ornithomimosaur from the Early Cretaceous of China. Proceedings of the Royal Society 277, 191-198.

- Marsh, O. C., 1877. Notice on new dinosaurian reptiles from the Jurassic formation. The American Journal of Science, Third Series 14, 514-516.

- Marsh, O. C., 1881. Classification of the Dinosauria. The American Journal of Science, Third series 23, 81-86.

- Marsh, O. C., 1890. Description of new dinosaurian reptiles. American Journal of Science 3, 81-86.

- Marsh, O. C., 1892. Notice of new reptiles from the Laramie Formation. American Journal of Science, Series 3, 43, 449-453.

- Nicholls, E. L., Russell, A. P., 1985. Structure and function of pectoral girdle and forelimb of Struthiomimus altus (Theropoda: Ornithomimidae). Paleontology 28, 643-677.

- Norell, M. A., Clark, J. M., Makovicky, P. J., 2002. Phylogenetic relationships among coelurosaurian dinosaurs. In: J. Gauthier and L. F. Gall (Eds.), New perspectives on the origin and early evolution of birds: Proceedings of the International Symposium in Honor of John H. Ostrom, Peabody Museum of Natural History, Yale University, New Haven, pp 49-67. 
- Osborn, H. F., 1905. Tyrannosaurus and other Cretaceous carnivorous dinosaurs. Bulletin of the American Museum of Natural History 21, 259-265.

- Osborn, H. F., 1916. Skeletal adaptation of Ornitholestes, Struthiomimus, Tyrannosaurus. Bulletin of the American Museum of Natural History 35, 733-771.

- Osborn, H. F., 1917. Skeletal adaptations of Ornitholestes, Struthiomimus, Tyrannosaurus. Bulletin of the American Museum of Natural History 35, 733-771.

- Osmólska, H., Roniewicz, E., Barsbold, R., 1972. A new dinosaur, Gallimimus bullatus n. gen., n. sp. (Ornithomimidae) from the Upper Cretaceous of Mongolia. Palaeontologica Polonica 27, 103-143.

- Owen, R., 1842. Report on British fossil reptiles, Part II. Report of the British Association for the Advancement of Science 11, 60-204.

- Parks, W. A., 1926. Struthiomimus brevitertius, a new species of dinosaur from the Edmonton Formation of Alberta. Transactions of Royal Society of Canada 20, 6570.

- Parks, W. A., 1928. Struthiomimus samueli, a new species of Ornithomimidae from the Belly River Formation of Alberta. University of Toronto Studies, Geological Series 26, 1-24.

- Parks, W. A., 1933. New species of dinosaurs and turtles from the Upper Cretaceous formations of Alberta. University of Toronto Studies, Geological Series 34, 1-33.

- Pérez-Moreno, B. P., Sanz, J. L., Buscalioni, A.D., Moratalla, J. J., Ortega, F., Rasskin-Gutman, D., 1994. A unique multitoothed ornithomimosaur dinosaur from the Lower Cretaceous of Spain. Nature 370, 363-367. 
- Pérez-Moreno. B.P., Sanz, J. L., 1995. The hand of Pelecanimimus polyodon: a preliminary report. II International Symposium of Lithographic Limestones. Ediciones de la Universidad Autónoma de Madrid (Extended Abstracts), 115-117.

- Pérez-Moreno, B. P., Sanz, J. L., 1995. The hand of Pelecanimimus polyodon: a preliminary report. II International Symposium on Lithographic Limestones. Ediciones de la Universidad Autónoma de Madrid (Extended Abstracts), 115-117.

- Russell, D. A., 1970. Tyrannosaurus from the Late Cretaceous of Western Canada. National Museum of Natural Sciences Publications in Palaeontology 1, 1-30.

- Russell, D. A., 1972. Ostrich dinosaurs from the Late Cretaceous of Western Canada. Canadian Journal of Earth Sciences 9, 375-402.

- Seeley, H. G., 1888. On the classification of the fossil animals commonly called Dinosauria. Proceedings of the Royal Society of London XLIII, 165-171.

- Sereno, P., 1999. The evolution of dinosaurs. Science 284, 2137-2147.

- Serrano-Brañas, C. I., Torres-Rodríguez, E., Reyes-Luna, P. C., González, I., González-León, C., 2014. Tyrannosaurid teeth from the Lomas Coloradas Formation, Cabullona Group (Upper Cretaceous) Sonora, Mexico. Cretaceous Research 49, 163-171.

- Smith, D., Galton, P., 1990. Osteology of Archaeornithomimus asiaticus (Upper Cretaceous, Iren Dabasu Formation, People's Republic of China). Journal of Vertebrate Paleontology 10, 255-265.

- Sternberg, C. M., 1933. A new Ornithomimus with complete abdominal cuirass. Canadian Field-Naturalist 47, 79-83. 
- Taliaferro, N. L., 1933. An occurrence of Upper Cretaceous sediments in northern Sonora, Mexico: Journal of Geology, 41, 12-37.

- Torres-Rodríguez, E., 2006. Terópodos del Cretácico Superior del Estado de Coahuila, México. Unpublished M.Sc. Thesis. Facultad de Ciencias, Universidad Nacional Autónoma de México, p. 91.

- Turner, A. H., Pol, D., Clarke, J. A., Erickson, G. M. and Norrell, M. A., 2007. A basal dromaeosaurid and size evolution preceding avian flight. Science 317, 13781381.

- Xu, X., Norell, M. A., Wang, X. - L., Makovicky, P. J., Wu, X. - C., 2002. A basal troodontid from the Early Cretaceous of China. Nature 415, 780-784.

- Xu, L., Kobayashi, Y., Lü, J., Lee, Y.N., Liu, Y., Tanaka, K., Zhang, X., Jia, S., and Zhang, J., 2011. A new ornithomimid dinosaur with northamerican affinities from the Late Cretaceous Quipa Formation in Henan Province of China. Cretaceous Research 32, 213-222.

\section{Figure Captions}

1. Study area and stratigraphic column of the Cabullona Group indicating the position of the Packard Shale Formation.

2. Manual phalanges of Tototlmimus packardensis gen. et sp. nov. (ERNO 8553) in multiple views: a. Distal facet of Ph I-1 in extensor (a1), flexor (a2), and distal (a3) views; b. Proximal facet of Ph III-1 in extensor (b1), flexor (b2), and proximal (b3) views; c. Proximal facet of Ph III-2 in extensor (c1), flexor (c2), and proximal (c3) views. 
3. Right metatarsals of Tototlmimus packardensis gen. et sp. nov. (ERNO 8553) in multiple views: a. Distal facet of metatarsal II in extensor (a1), lateral (a2), medial (a3), and flexor (a4) views; b. Distal facet of metatarsal III in extensor (b1), lateral (b2), medial (b3), and flexor (b4) views; c. Distal facet of metatarsal IV in extensor (c1), lateral (c2), medial (c3), and flexor (c4) views; d. Articulated metatarsals in extensor (d1) and distal (d2) views. Abbreviations: sgin, semiginglymoid articulation; II, metatarsal II; III, metatarsal III; IV, metatarsal IV. White arrows point to scars and pits.

4. Pedal phalanges of Tototlmimus packardensis gen. et sp. nov. (ERNO 8553) in multiple views: a. Proximal facet of right phalanx III-1 in extensor (a1), flexor (a2), and proximal (a3) views; b. Proximal facet of right phalanx II-1 in extensor (b1), flexor (b2), lateral (b3), and proximal (b4) views; c. Proximal facet of right phalanx III-2 in extensor (c1), flexor (c2), and proximal (c3) views; d. Proximal facet of right phalanx IV-1 in extensor (d1), flexor (d2), lateral (d3), and proximal (d4) views.

5. Pedal phalanges of Tototlmimus packardensis gen. et sp. nov. (ERNO 8553) in multiple views: a. Right phalanx II-2 in extensor (a1), flexor (a2), lateral (a3), proximal (a4), and distal (a5) views; b. Right phalanx III-3 in extensor (b1), flexor (b2), lateral (b3), proximal (b4), and distal (b5) views; c. Right phalanges IV-3 and IV-4 in extensor (c1), flexor (c2), lateral (c3), and medial (c4) views; d. Left pedal ungual in lateral (d1), medial (d2), extensor (d3), and articular (d4). Abbreviations: sul, sulcus; Kl, keel.

6. Metatarsals of Asian and North American ornithomimids including Tototlmimus packardensis in extensor view: (a) Harpymimus okladnikovi (GIN 100/29; from 
Kobayashi and Barsbold, 2005); (b) Garudimimus brevipes (GIN 100/13; from Kobayashi and Barsbold, 2005); (c) Gallimimus sp. (GIN 100/14; from Kobayashi and Barsbold, 2005); (d) Ornithomimus velox (YM 542; from Osborn, 1916); (e) Struthiomimus altus (Tmp1994.126.001); (f) Struthiomimus altus (UCMZ 1980.1); (g) Tototlmimus packardensis (ERNO 8553). Abbreviations: II, metatarsal II; III, metatarsal III; IV, metatarsal IV. Scale bar $5 \mathrm{~cm}$.

7. Comparison of distal ends of metatarsal III of North American ornithomimids in extensor view: (a) Tototlmimus packardensis (ERNO 8553); (b) Struthiomimus altus (UCMZ 1980.1); (c) Struthiomimus altus (AMNH 5385); (d) Ornithomimus affinis (5684 USNM). Black arrow points to semi-ginglymoid articulation (sgin). Scale bar $1 \mathrm{~cm}$.

8. Comparison of pedal unguals of North American ornithomimids in lateral (1), medial (2), dorsal (3) and ventral (4) views: (a) Ornithomimus sp. (365556 USNM); (b) Ornithomimus sp. (6107 USNM); (c) Struthiomimus altus (Tmp1967.008.0047); (d) Struthiomimus altus (Tmp1967.008.0049); (d) Tototlmimus packardensis (ERNO 8553). Black arrow points to the shallow groove in medial side and to the deep sulcus in the ventromedial edge. Scale bar 1 $\mathrm{cm}$.

9. Comparison of pedal unguals of North American ornithomimids "Struthiomimus" sp. and Tototlmimus packardensis in lateral view: (a) Tototlmimus packardensis (ERNO 8553); (b) “Struthiomimus”sp. (AMNH 5247); (c) "Struthiomimus” sp. (Tmp1990.26.1). Black arrow points to the deep sulcus in the ventromedial edge. Scale bar $1 \mathrm{~cm}$. 
10. Results of the phylogenetic tree analysis between Tototolmimus packardensis and main coelurosaurians taxa using TNT software: Strict consensus tree showing the position of Tototolmimus packardensis within Ornithomimosauria.

11. Results of the phylogenetic tree analysis between Tototolmimus packardensis and other ornithomimosaurs using TNT software : (a) Strict consensus tree of ornithomimosaurs showing an unresolved polytomy between Struthiomimus, Ornithomimus, Sinornithomimus and Tototlmimus; (b) Tree showing the position of Tototlmimus within Ornithomimidae based on the arctometatarsalian condition (character 34); (c) Tree showing the phylogenetic position of Tototlmimus within the "Northamerican clade" proposed by Kobayashi and Lü (2003). Tree topologies to the level of Archaeornithomimus are identical.

\section{Table Captions}

Table 1. Measurements of Tototlmimus packardensis.

Table 2. Specimens and references used for phylogenetic analysis including Tototlmimus packardensis (Modified from Kobayashi and Lü, 2003).

\section{Appendices Captions}

Appendix 1. List of characters and character state used for the phylogenetic analysis between Tototolmimus packardensis and main coelurosaurians groups (Makovicky et al., 2010).

Appendix 2. Data matrix used for phylogenetic analysis of Tototlmimus packardensis and main coelurosaurians groups. Missing or unknown characters are represented by “?”. 
Appendix 3. List of characters used for the phylogenetic analysis between Tototolmimus packardensis and other ornithomimosaurs (Kobayashi and Lü, 2003; Makovicky et al., 2010).

Appendix 4. Data matrix used for phylogenetic analysis of Tototlmimus packardensis within Ornithomimosauria. Missing or unknown characters are represented by “?”. 
Table 1.- Measurements of Tototlmimus packardensis (ERNO 8553).

\begin{tabular}{|l|c|c|c|c|}
\hline SPECIMEN & ELEMENT & SIDE & $\begin{array}{c}\text { LENGTH } \\
(\mathbf{m m})\end{array}$ & $\begin{array}{c}\text { WIDTH } \\
(\mathbf{m m})\end{array}$ \\
\hline ERNO 8553 & Distal manual phalanx I-1 & Left & 15 & 21 \\
\hline & Proximal manual phalanx III-1 & Left & 15 & 25 \\
\hline & Proximal manual phalanx III-2 & Left & 21 & 23 \\
\hline & Distal metatarsal II & Right & 65 & 35 \\
\hline & Distal metatarsal III & Right & 55 & 47 \\
\hline & Distal metatarsal IV & Right & 70 & 20 \\
\hline & Proximal pedal phalanx II-1 & Left & 30 & 40 \\
\hline & Proximal pedal phalanx II-1 & Right & 30 & 50 \\
\hline & Pedal phalanx II-2 & Right & 41 & 32 \\
\hline & Pedal phalanx II-2 & Left & 41 & 28 \\
\hline & Proximal pedal phalanx III-1 & Left & 35 & 30 \\
\hline & Proximal pedal phalanx III-2 & Right & 32 & 40 \\
\hline & Pedal phalanx III-3 & Right & 38 & 25 \\
\hline & Proximal pedal phalanx IV-1 & Right & 32 & 40 \\
\hline & Pedal phalanx IV-3 & Right & 25 & 31 \\
\hline & Pedal phalanx IV-4 & Right & 22 & 29 \\
\hline & Pedal ungual & Left & 38 & 22 \\
\hline
\end{tabular}



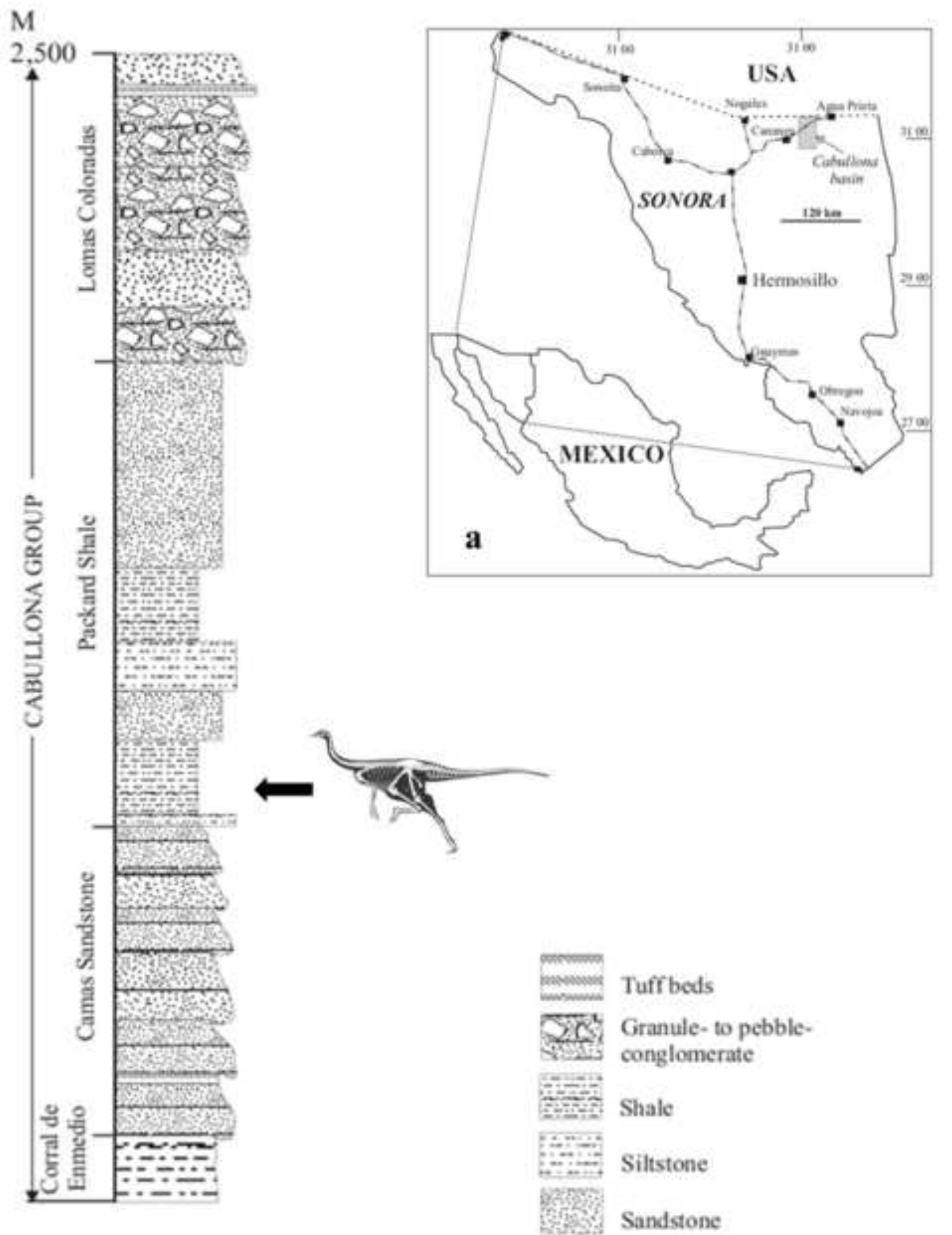

manes

Shale

Siltstone

Sandstone 


\section{Figure 2}

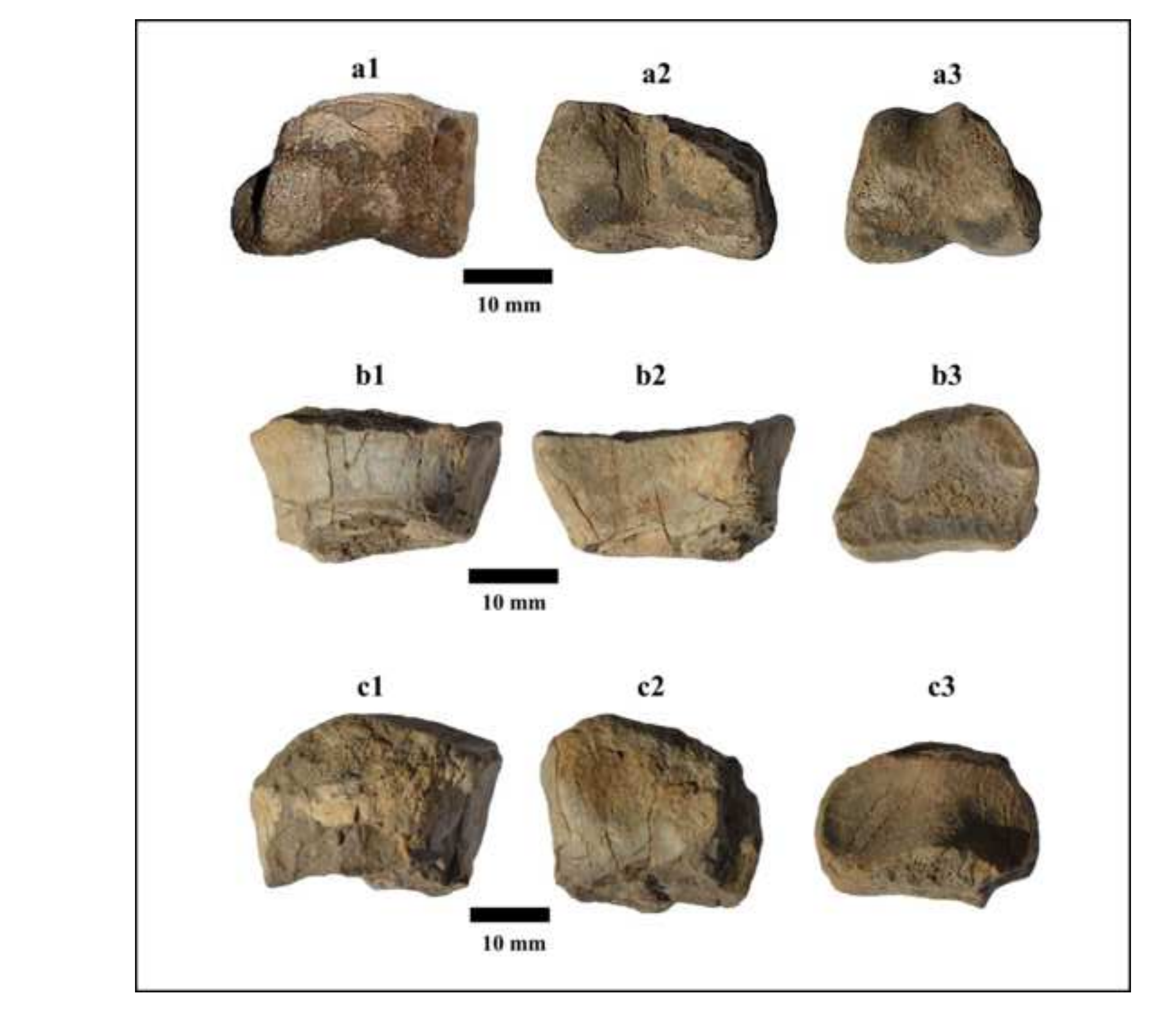


Figure 3

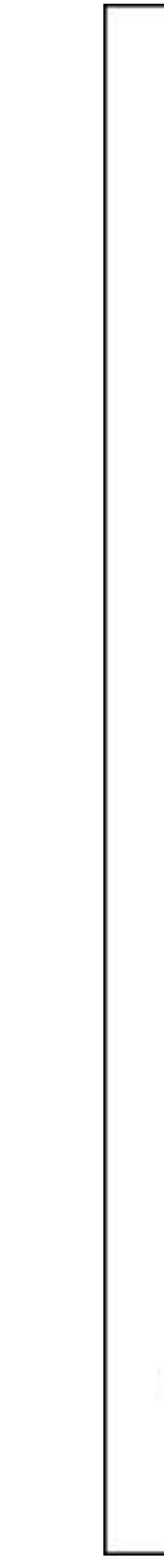

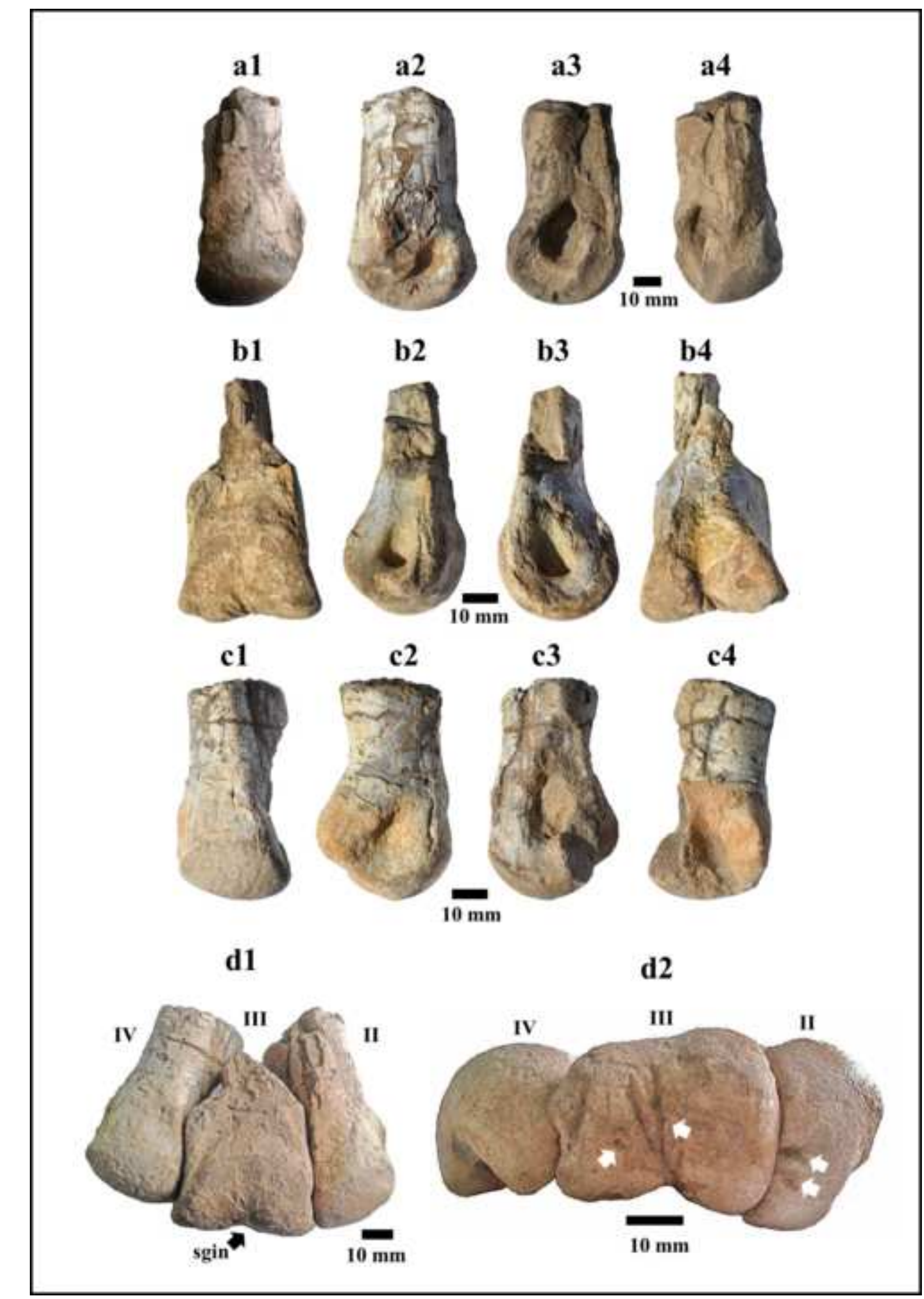

d1 d2 
Figure 4
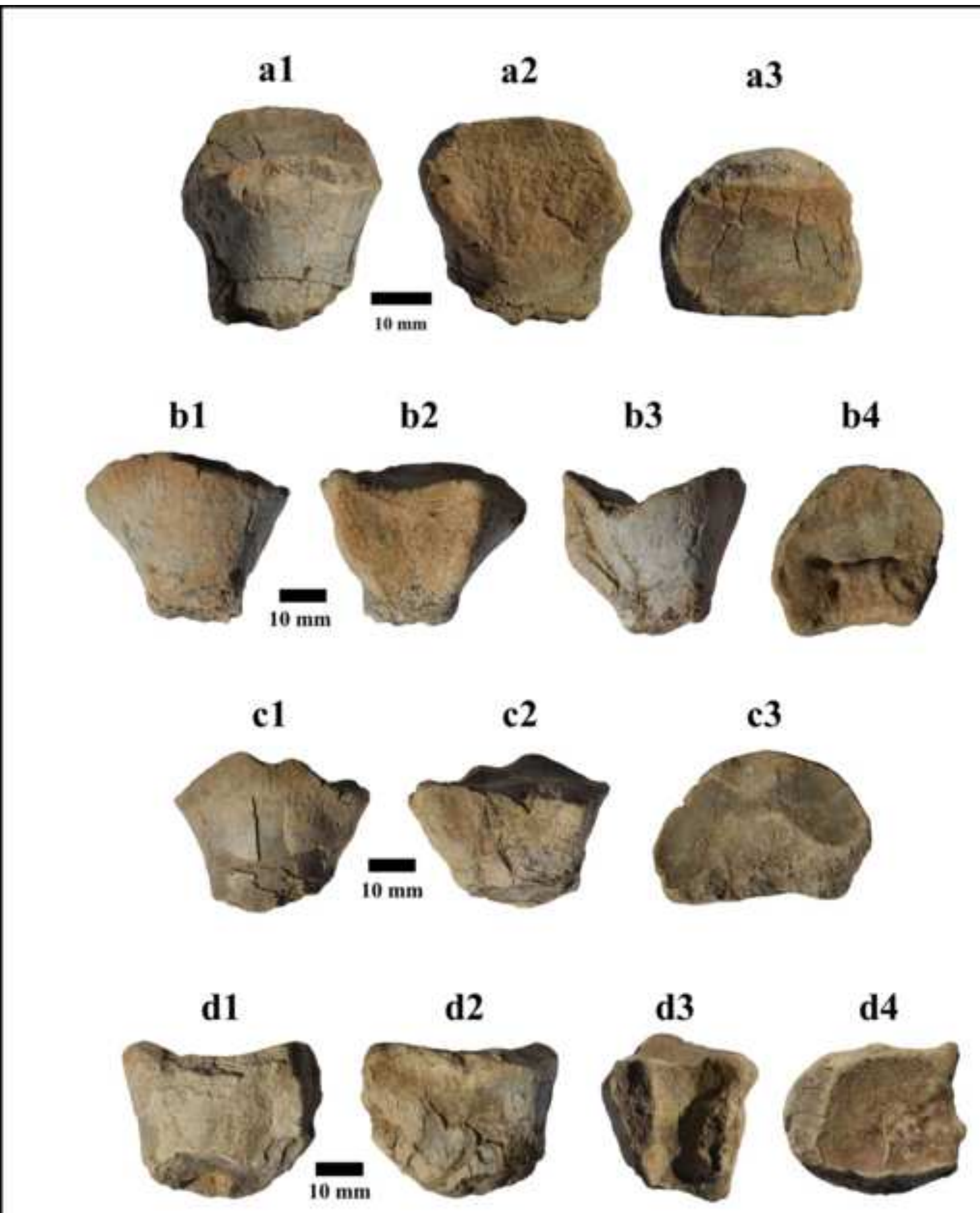

b2

b3

b4
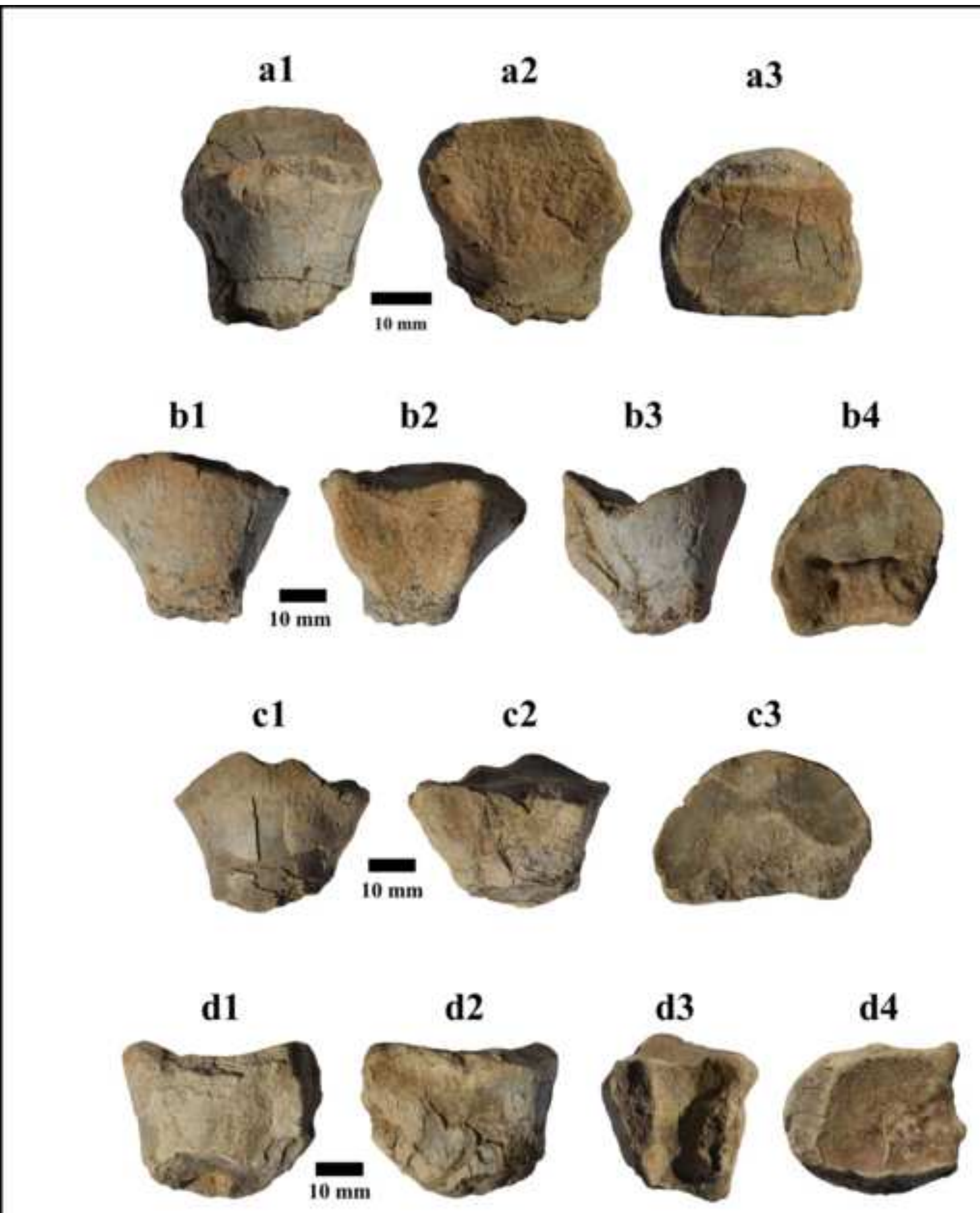

c3
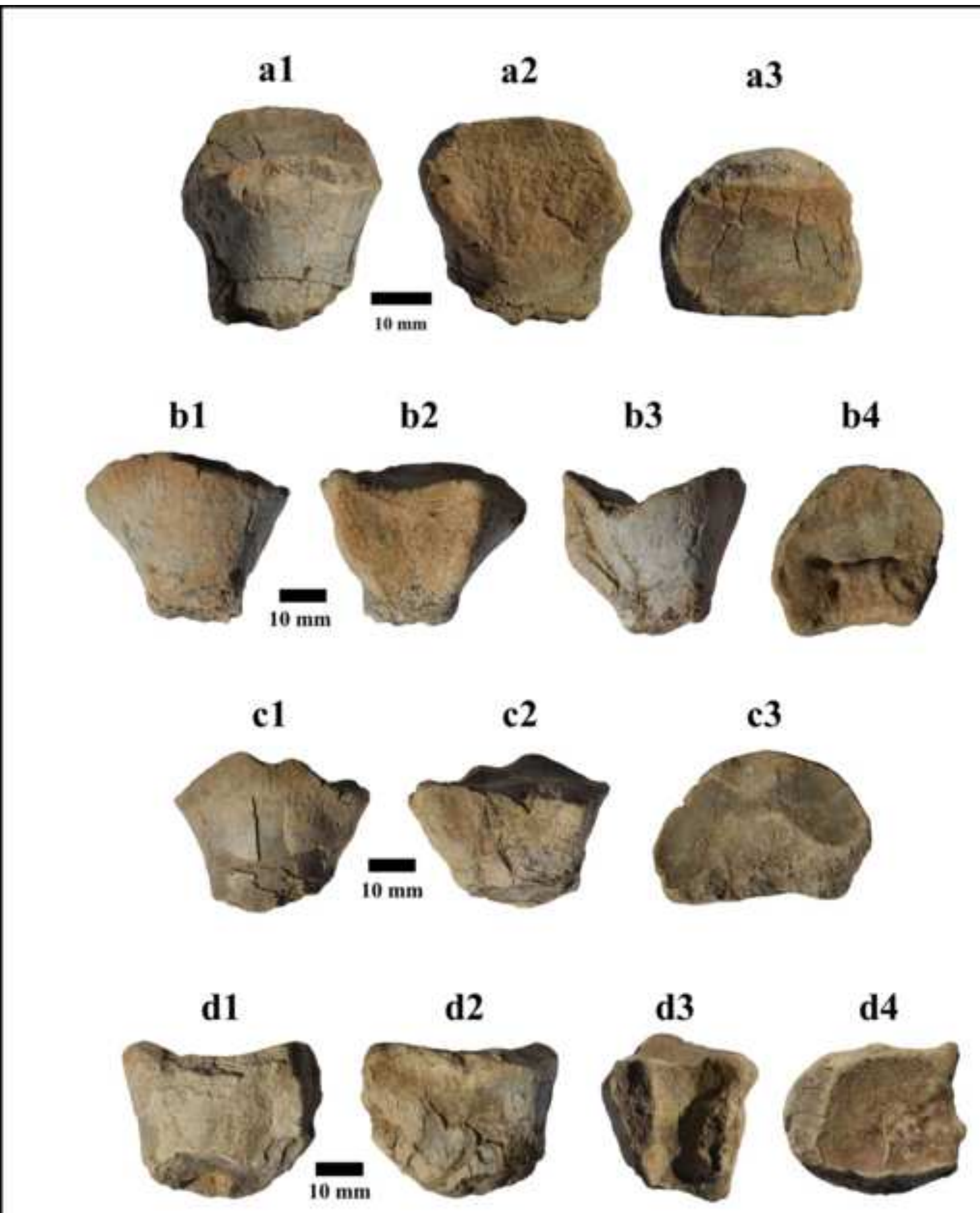

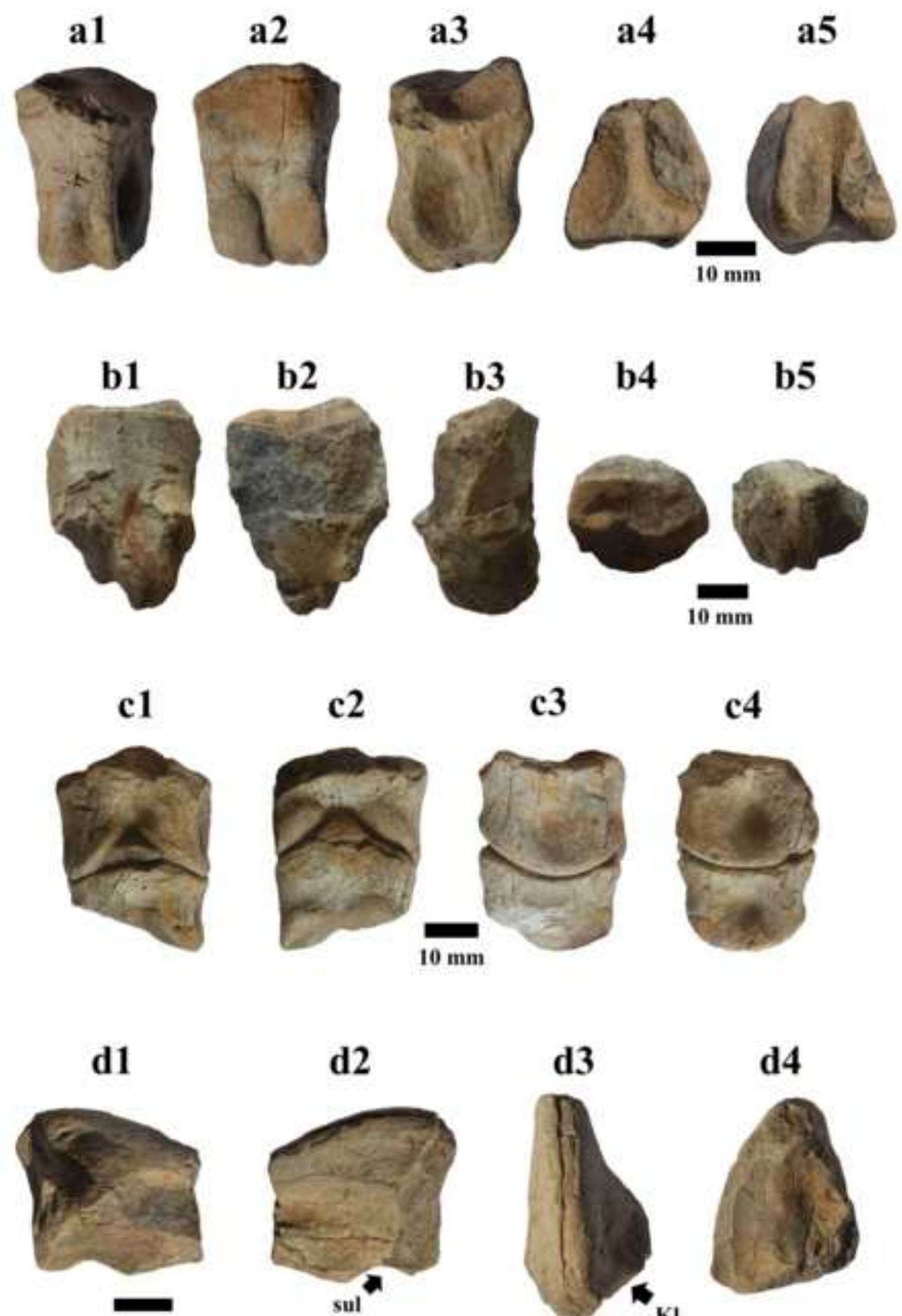

c3

c4
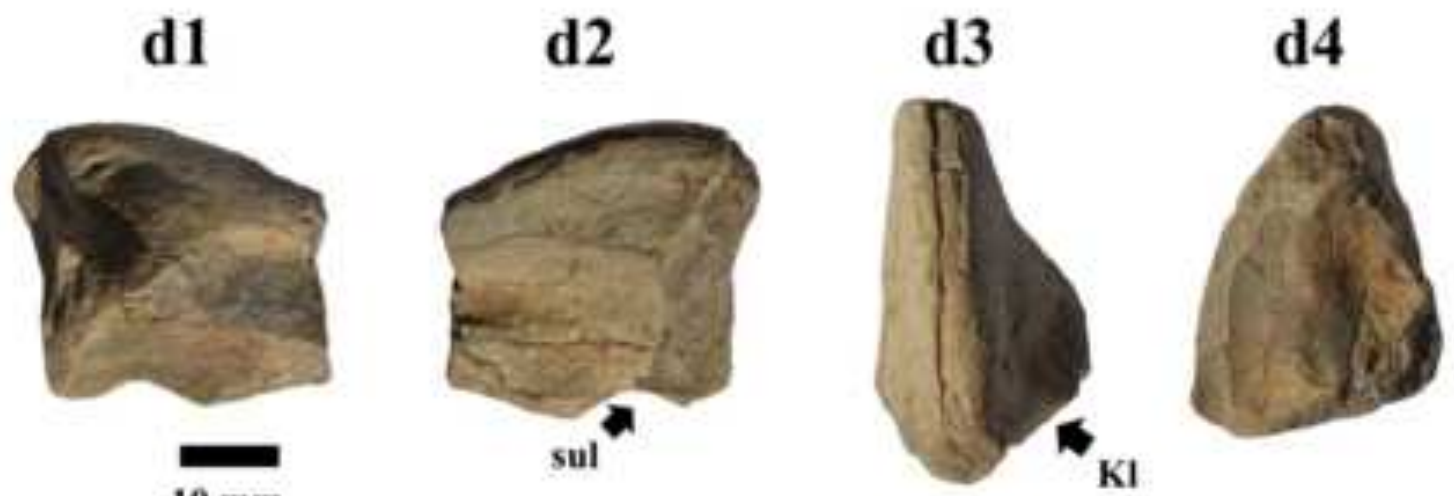

$10 \mathrm{~mm}$ 


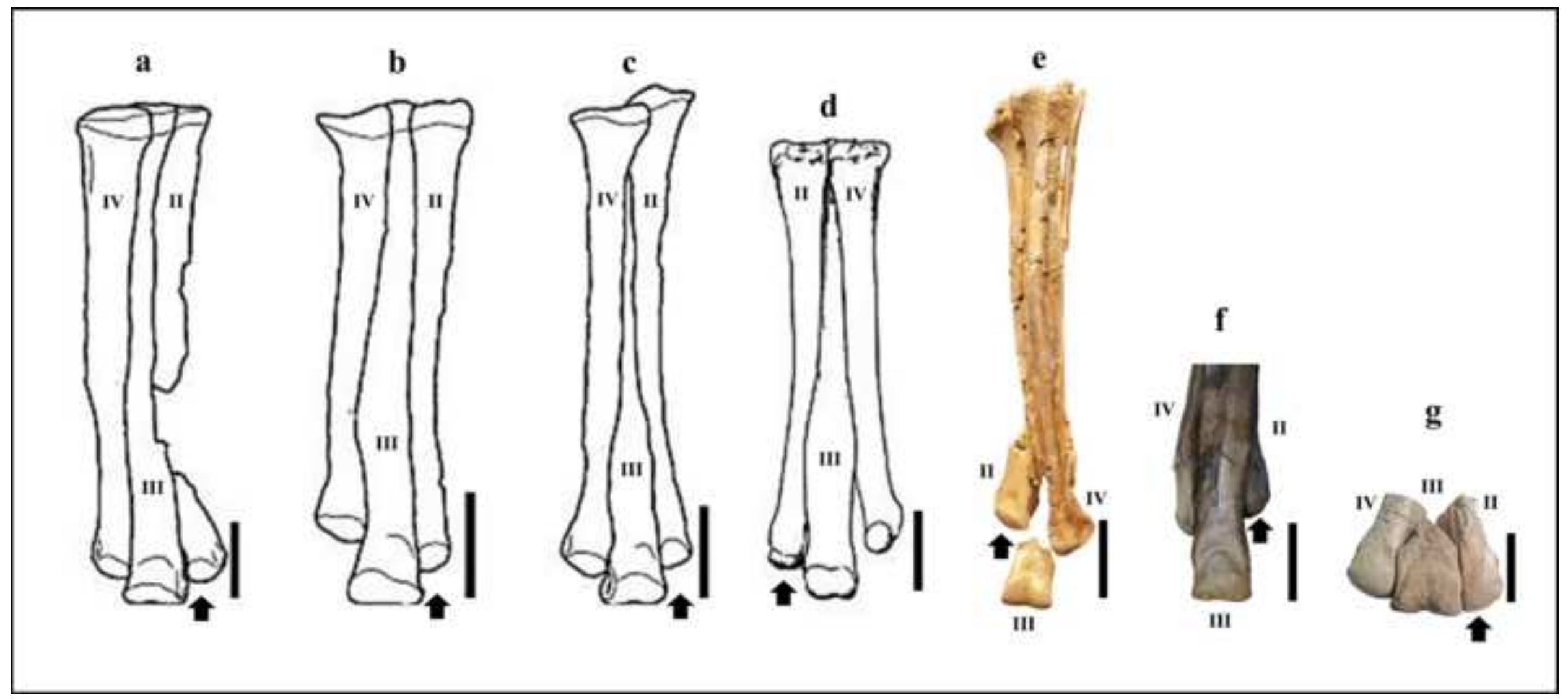


Figure 7
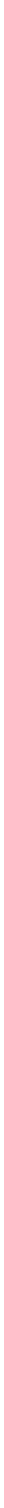


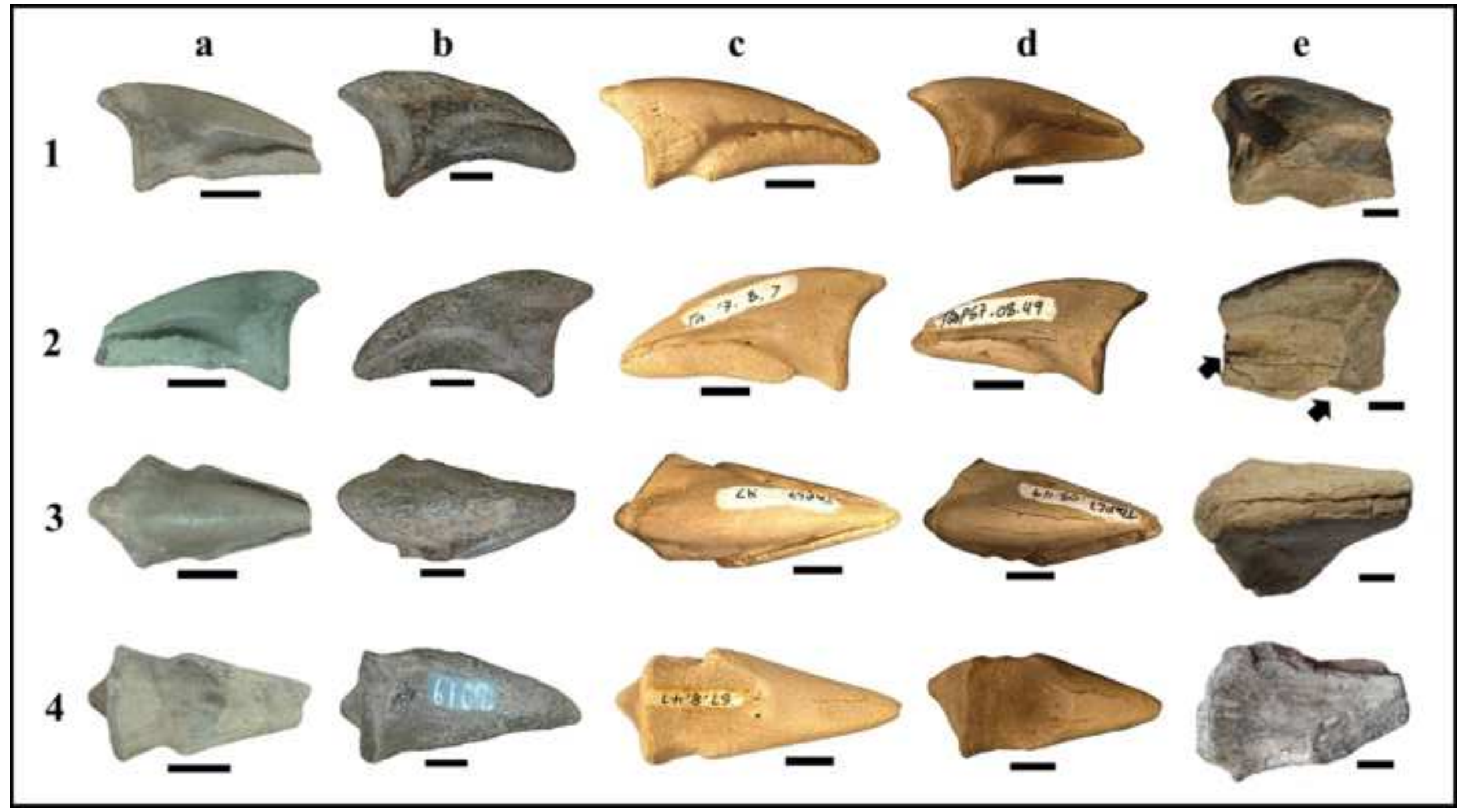




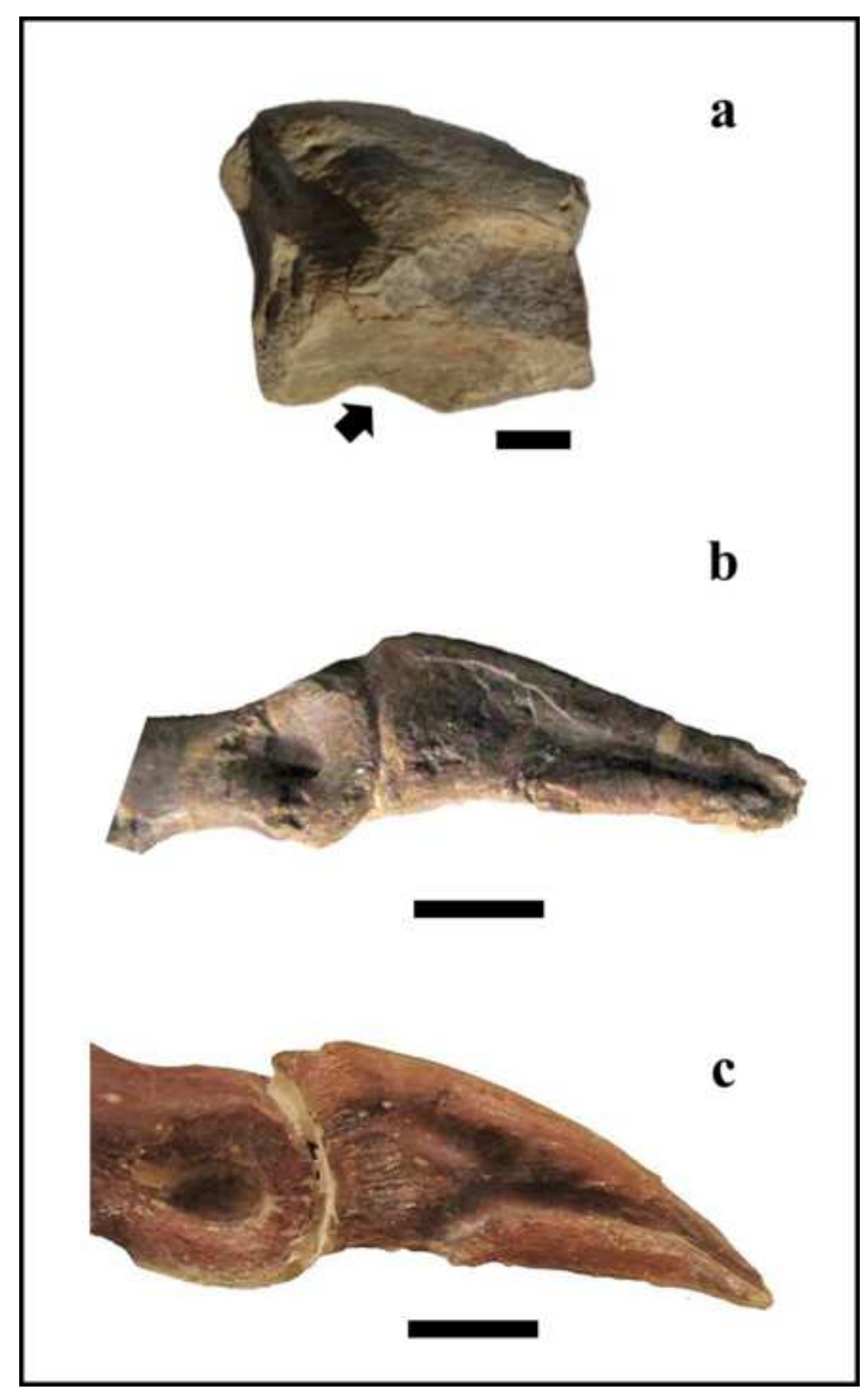

Figure 9

a

b

$$
\text { ( }
$$

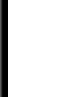

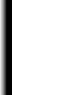

$$
\text { D. }
$$

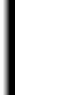


Delophesauru.

- Sinrapter

Ornitholestes

Huaslagnathes

- Dilong

Sinosaurepterys

Compsognathus

Ceelunus

Newsebasauris

Tanycelagrevs

Proceratesaurus

Monedophosaurus

Ouanlong

Eotyrannus

Allosanus

- Appalachlosaurus

- xomoguantong

Tyrannosaurus

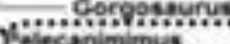

-) Lelecaniminus

t Dhenzousanas

: Harpymimus

: Eelahandong

$\vdots$ Corudimimus

L Struthiemimus $\quad$ Gallimimus

\begin{tabular}{l|l}
$\vdots$ & Calliminus \\
$\vdots$ & Ornithomimus
\end{tabular}

\begin{tabular}{l|l} 
& Archoeornithomimus \\
Anserimimus
\end{tabular}

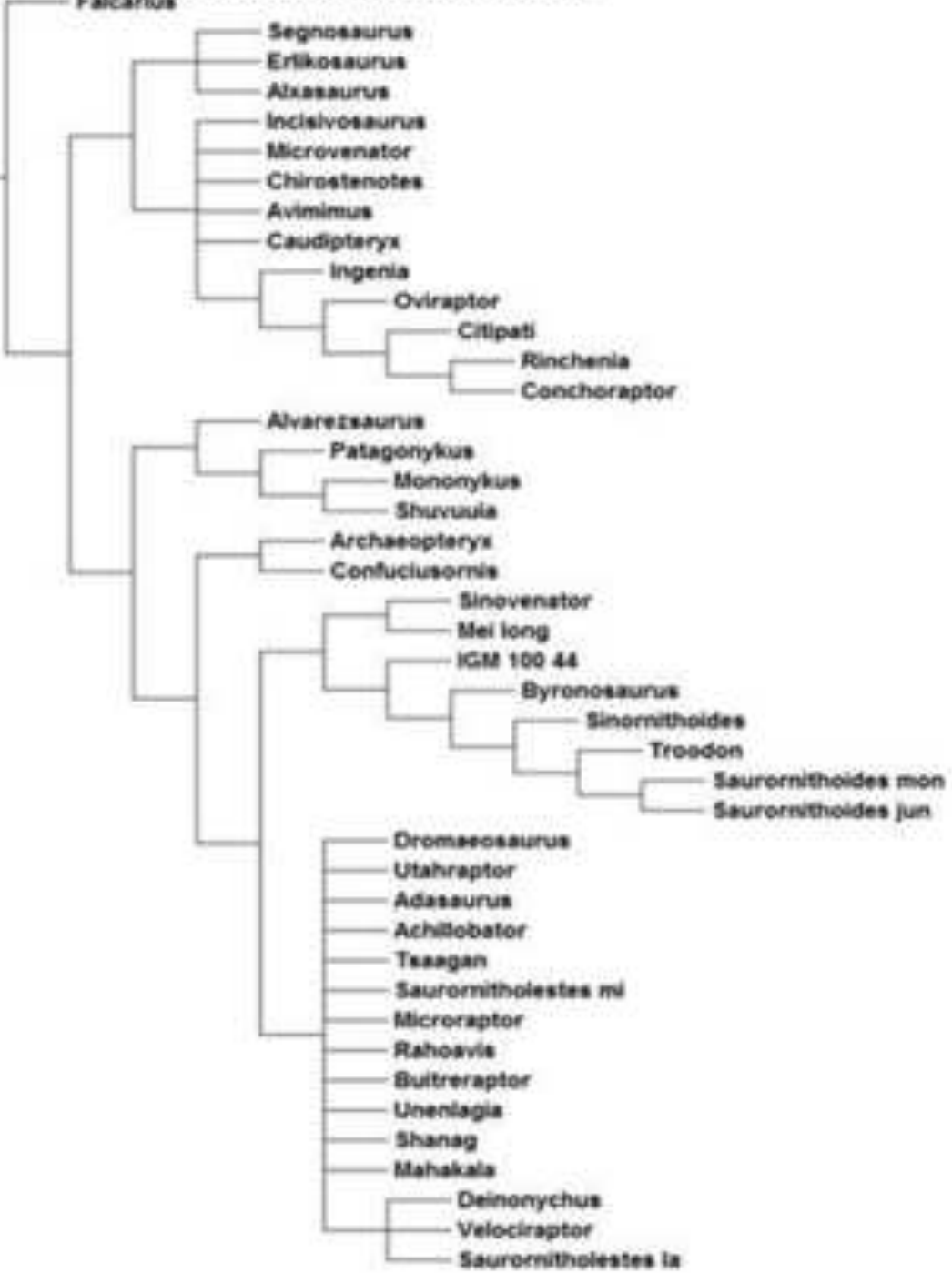

Sauroenithelestes in 
Figure 11

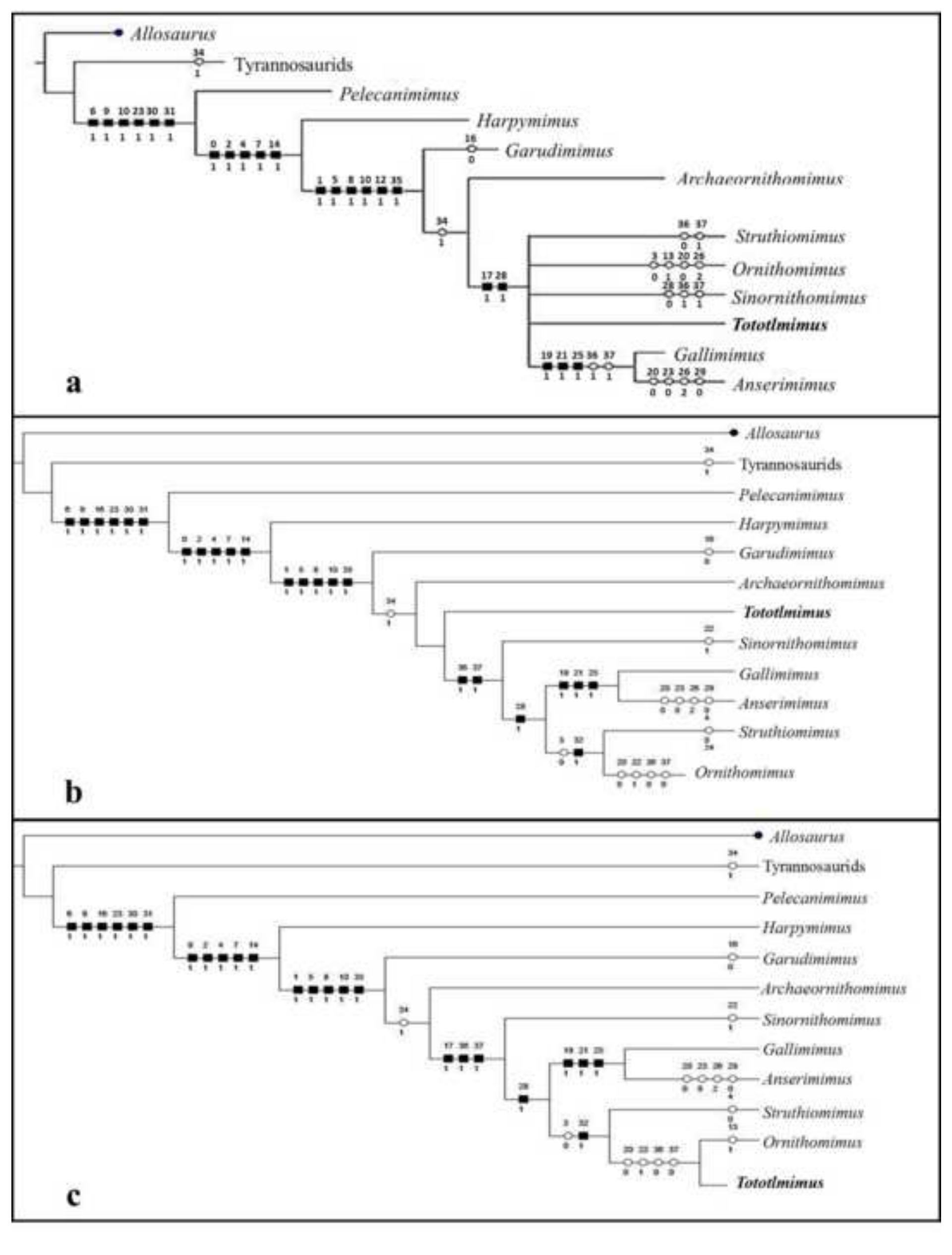


Table 2.- Measurements of Tototlmimus packardensis (ERNO 8553).

\begin{tabular}{|c|c|c|c|c|}
\hline SPECIMEN & ELEMENT & SIDE & $\begin{array}{c}\text { LENGTH } \\
(\mathbf{m m})\end{array}$ & $\begin{array}{c}\text { WIDTH } \\
(\mathbf{m m})\end{array}$ \\
\hline ERNO 8553 & Distal manual phalanx I-1 & Left & 15 & 21 \\
\hline & Proximal manual phalanx III-1 & Left & 15 & 25 \\
\hline & Proximal manual phalanx III-2 & Left & 21 & 23 \\
\hline & Distal metatarsal II & Right & 65 & 35 \\
\hline & Distal metatarsal III & Right & 55 & 47 \\
\hline & Distal metatarsal IV & Right & 70 & 20 \\
\hline & Proximal pedal phalanx II-1 & Left & 30 & 40 \\
\hline & Proximal pedal phalanx II-1 & Right & 30 & 50 \\
\hline & Pedal phalanx II-2 & Right & 41 & 32 \\
\hline & Pedal phalanx II-2 & Left & 41 & 28 \\
\hline & Proximal pedal phalanx III-1 & Left & 35 & 30 \\
\hline & Proximal pedal phalanx III-2 & Right & 32 & 40 \\
\hline & Pedal phalanx III-3 & Right & 38 & 25 \\
\hline & Proximal pedal phalanx IV-1 & Right & 32 & 40 \\
\hline & Pedal phalanx IV-3 & Right & 25 & 31 \\
\hline & Pedal phalanx IV-4 & Right & 22 & 29 \\
\hline & Pedal ungual & Left & 38 & 22 \\
\hline
\end{tabular}


Table 2. Specimens and references used for phylogenetic analysis within Ornithomimosauria (Modified from Kobayashi and Lü, 2003).

\begin{tabular}{|c|c|}
\hline TAXA & SOURCE \\
\hline $\begin{array}{l}\text { Allosaurus } \\
\text { Allosaurus fragilis Marsh, } 1877\end{array}$ & Madsen, 1976 \\
\hline $\begin{array}{l}\text { Tyranosauridae } \\
\text { Tyrannosaurus rex Osborn, 1905 } \\
\text { Albertosaurus libratus (Lambe, 1914) } \\
\text { Daspletosaurus torosus Russell, } 1970\end{array}$ & $\begin{array}{l}\text { Osborn, 1905; Osborn, 1916; Bakker et al. 1988; } \\
\text { Carr, } 1999 \\
\text { Carr, } 1999 \\
\text { Russell, 1970; Carr, } 1999\end{array}$ \\
\hline $\begin{array}{l}\text { Pelecanimimus } \\
\text { Pelecanimimus polyodon Pérez-Moreno, Sanz, } \\
\text { Buscalioni, Moratalla, Ortega and Rasskin-Gutman, } 1994\end{array}$ & Pérez-Moreno et al. 1994 \\
\hline $\begin{array}{l}\text { Harpymimus } \\
\text { Harpymimus okladnikovi Barsbold and Perle, } 1984\end{array}$ & GIN 100/29; Barsbold and Perle, 1984 \\
\hline $\begin{array}{l}\text { Garudimimus } \\
\text { Garudimimus brevipes Barsbold, } 1981\end{array}$ & GIN 100/13; Barsbold, 1981 \\
\hline $\begin{array}{l}\text { Archaeornithomimus } \\
\text { Archaeornithomimus asiaticus (Gilmore, 1933) }\end{array}$ & $\begin{array}{l}\text { AMNH 6565-6569, AMNH 21797, AMNH } \\
\text { 21779-21801, AMNH 21803, AMNH 21884- } \\
\text { 21892; Gilmore, 1933; Smith and Galton, } 1990\end{array}$ \\
\hline $\begin{array}{l}\text { Sinornithomimus } \\
\text { Sinornithomimus dongi Kobayashi and Lü, } 2003\end{array}$ & IVPP-V11797-10; Kobayashi and Lü, 2003 \\
\hline $\begin{array}{l}\text { Gallimimus } \\
\text { Gallimimus bullatus Osmólska, Roniewicz and Barbold, } \\
1972 \\
\text { Gallimimus sp. }\end{array}$ & $\begin{array}{l}\text { GIN 100/10, GIN 100/11, GIN 100/12, GIN } \\
\text { 100/1133; Osmóslka et al. } 1972 \\
\text { GIN 950818, GIN 100/14 }\end{array}$ \\
\hline $\begin{array}{l}\text { Struthiomimus } \\
\text { Struthiomimus altus Lambe, } 1902 \\
\text { Struthiomimus sp. }\end{array}$ & $\begin{array}{l}\text { ROM 1790, UCMZ(VP)1980.1; Osborn, 1916; } \\
\text { Russell, 1972; Nicholls and Russell, } 1985 \\
\text { TMP 90.26.1 }\end{array}$ \\
\hline Ornithomimus & \\
\hline $\begin{array}{l}\text { Ornithomimux velox Marsh, } 1890 \\
\text { Ornithomimus edmontonicus Sternberg, } 1933\end{array}$ & $\begin{array}{l}\text { Marsh, 1890; DeCourten and Russell, } 1985 \\
\text { ROM 851; Sternberg, 1933; Parks, 1933; Russell, } \\
1972\end{array}$ \\
\hline Ornithomimus affinis & $\begin{array}{l}\text { USNM 5453, USNM 5684, USNM 5703, USNM } \\
\text { 5704, USNM 6108, USNM 8456, USNM } \\
00167250\end{array}$ \\
\hline Ornithomimus tenius & USNM 514 \\
\hline Ornithomimus sp. & $\begin{array}{l}\text { USNM 5815, USNM 00356137, USNM 365556, } \\
\text { TMP 95.110.1, TMP 93.62.1 }\end{array}$ \\
\hline $\begin{array}{l}\text { Dromiceiomimus } \\
\text { Dromiceiomimus brevitertius (Parks,1926) } \\
\text { Dromiceiomimus samueli (Parks, 1928) }\end{array}$ & $\begin{array}{l}\text { ROM 797, ROM 852; Parks, 1926;Russell, } 1972 \\
\text { ROM 840; Parks, 1928; Russell, } 1972\end{array}$ \\
\hline $\begin{array}{l}\text { Anserimimus } \\
\text { Anserimimus planinychus Barsbold } 1988\end{array}$ & GIN 100/300; Barsbold, 1988 \\
\hline $\begin{array}{l}\text { Tototlmimus } \\
\text { Tototlmimus packardensis }\end{array}$ & ERNO 8553 \\
\hline
\end{tabular}

